\title{
Enteritis-associated Acute Febrile Neutrophilic Dermatosis with Acute Monoarthritis
}

\author{
Stamatis S. Papadatos ${ }^{1,2}$, Christos Zissis ${ }^{2}$, Georgios Deligiannis ${ }^{2}$, Stefanos Mylonas ${ }^{2}$ \\ $13^{\text {rd }}$ Department of Internal Medicine, National and Kapodistrian University of Athens Medical School, Sotiria General Hospital \\ of Athens, Greece \\ $22^{\text {nd }}$ Department of Internal Medicine, General Hospital of Trikala, Thessaly, Greece
}

\section{Correspondence:}

Stamatis S. Papadatos, $3^{\text {rd }}$ Department of Internal Medicine, National and Kapodistrian University of Athens Medical School, Sotiria General Hospital of Athens, Greece

152 Mesogeion Ave, Athens, Greece

E mail:stamspap@gmail.com

Tel:+306973750882

Received: 18 Feb 2017

Accepted: 21 May 2017

Published Online: 29 May 2017

Published: 22 Dec 2017

Key words: Sweet syndrome, rash, monoarthritis, viral enteritis

Citation: Papadatos SS, Zissis C, Deligiannis G, Mylonas S. Enteritis-associated acute febrile neutrophilic dermatosis with acute monoarthritis.

Folia Medica 2017;59(4):477-80. doi:10.1515/folmed-2017-0057
Febrile neutrofilic dermatosis is an uncommon entity with complex pathophysiology, usually secondary to an infection, a malignancy or an autoimmune disease. Extracutaneous manifestations of the disease are very rare as well. We report a patient with histologically confirmed acute febrile neutrophilic dermatosis caused by viral enteritis that was presented with painful rash along with acute monoarthritis and treated with oral corticosteroids.

\section{INTRODUCTION}

Sweet syndrome (SS) (acute febrile neutrophilic dermatosis) is an uncommon entity with specific clinical and histopathological characteristics. The predominant clinical feature of painful, asymmetric, reddish skin lesions reflects the microscopic image of diffuse upper dermal infiltrate of mature neutrophils and is usually accompanied by signs and symptoms including pyrexia $>38^{\circ} \mathrm{C}$, malaise and arthralgias. Based on its etiology, SS is divided into idiopathic, malignancy-related and drug-related. ${ }^{1}$ A pregnancyassociated form has also been reported. ${ }^{2}$ In some cases, extracutaneous involvement may occur. ${ }^{3}$ The main characteristic of the syndrome is the dramatic response to oral corticosteroids. Improvement is also feasible by controlling the underlying disease which may be a solid or a hematological malignancy, an infection or an autoimmune disease.

\section{CASE PRESENTATION}

A 68-year-old male smoker, with a medical history of hypertension treated with irbesartan for the last eleven years presented to our hospital complaining about diarrhea which initiated five days ago, and fever. He also reported gradually established fatigue and skin rashes localized in his extremities and chest and causing burning pain (Fig. 1A,B). He reported neither history of allergies, nor newly started medications, environmental exposures and use of chemicals. Upon physical examination his temperature was $37.9^{\circ} \mathrm{C}$. The distal interphalangeal joint of his third right finger was swollen and painful without any previous reported injury, compatible with acute monoarthritis (Fig. 1C). The abdominal ultrasonography as well as the chest $X$ ray was normal and the right hand $X$-ray revealed neither bone lysis nor signs of chronic arthritis. 
The initial laboratory tests revealed white blood cell count of $12.9 \times 10^{9} / \mathrm{L}$ with $77.5 \%$ neutrophils. The erythrocyte sedimentation rate was $65 \mathrm{~mm} / \mathrm{h}$ while the C-reactive protein levels were $7.5 \mathrm{mg} /$ $d L$. Biochemical parameters, including uric acid levels, were all normal. Fecal and blood cultures did not detect any pathogen. Skin lesion biopsy revealed neutrophilic dermatosis without vasculitis, consistent with SS (Fig. 1D). Further investigation for malignancies or autoimmune diseases was then performed. The whole body CT scan was normal, as were esophagogastroduodenoscopy and colonoscopy. Tumor markers Ca 19-9, alpha-fetoprotein $(a-F P)$, carcinoembryonic antigen (CEA) and serum prostate-specific antigen (PSA) were within normal limits and the peripheral blood smear was not suspicious for hematological malignancy. Reumatology tests, namely rheumatoid factor (RF), antinuclear antibodies (ANA), anti-neutrophil cytoplasmic antibodies (ANCA), anti-cyclic citrullinated peptide antibodies (anti-CCP) and anti-double stranded DNA antibodies (anti-dsDNA) were all negative. The patient was initially treated with intravenous solutions with potassium chloride and anti-diarrheal diet and he started a one-month tapering course of per os prednizolone with gradual resolution of the rashes (without scarring) and the monoarthritis. Six months after discharge he remains free of symptoms.

\section{DISCUSSION}

Acute febrile neutrophilic dermatosis is a reactive process occurring in response to systemic factors, such as inflammation, hematologic disease, infection, or drug exposure. ${ }^{4}$ Despite the fact that the pathogenesis of SS has not been totally determined, cytokines seem to have an etiologic role. Granulocyte colony-stimulating factor (G-CSF), granulocyte macrophage colony-stimulating factor (GM-CSF), interferon-gamma (IFN- $\gamma)$, interleukin 1 (IL-1), IL-3, IL-6, and IL-8 are potential candidates in the pathogenesis of SS. ${ }^{5}$ The relationship between SS and cancer is strong; it is suggested that it may be an indicator of underlying malignancy or its relapse. ${ }^{6}$ Hematologic malignancies are thought to be more common causes of SS compared to solid tumors and acute myeloid leukemia seems to be the predominant one. ${ }^{6}$ On this context, our patient underwent cancer screening tests and the possibility of malignancy was ruled out. Drug-induced SS has been associated with antibiotics, antiviral and antifungal agents, granulocyte-colony stimulating factor (G-CSF), non-steroidal anti-inflammatory drugs (NSAIDs), vaccines and even proton pump inhibitors (PPIs). ${ }^{7}$ None of these agents had been administered to our patient before the onset of symptoms. Multiple infections have been associated with SS and the upper respiratory tract Streptococcal
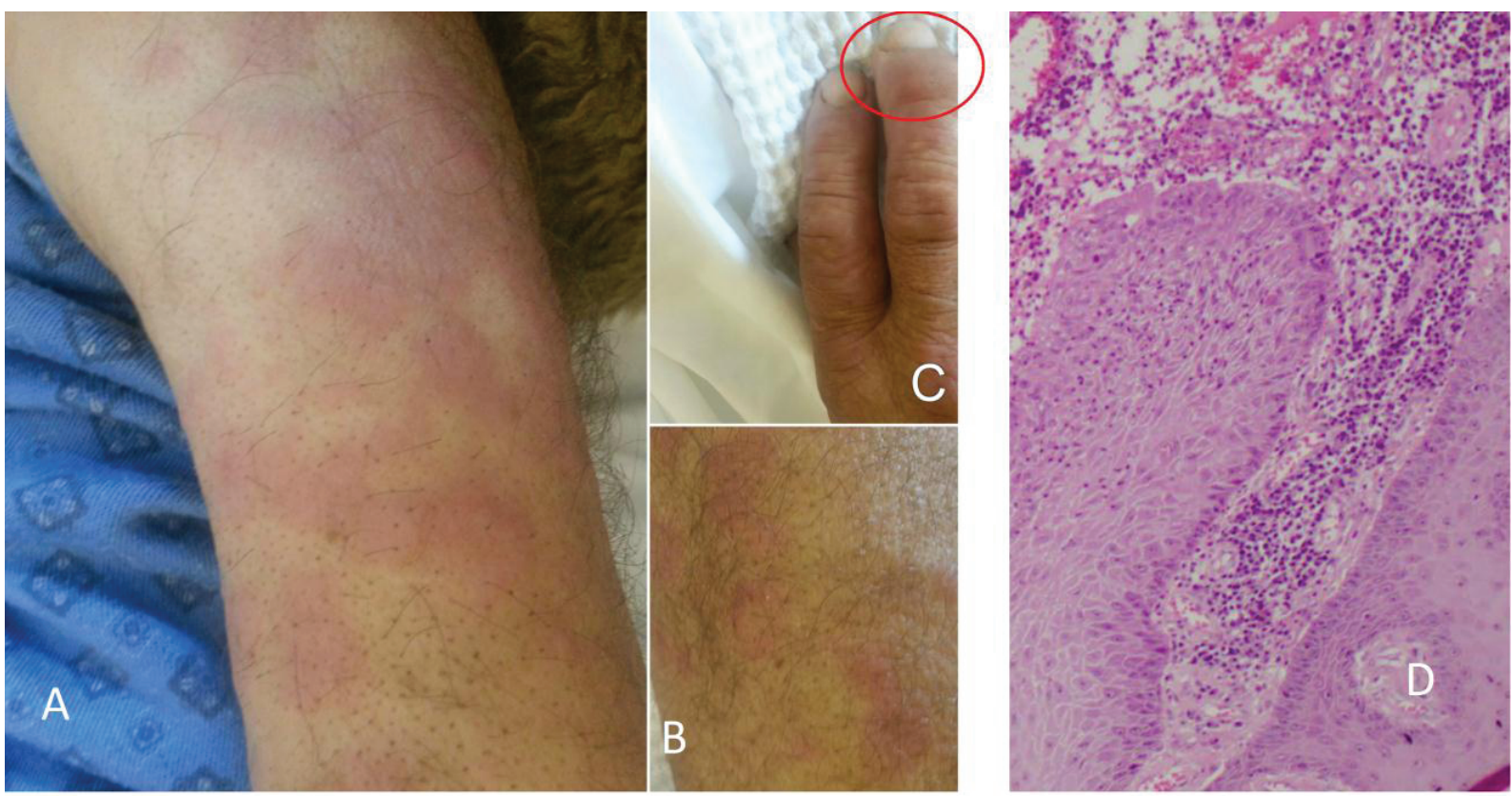

Figure 1. A-B: The asymmetric, reddish skin lesions in the patient's extremities. C: The distal interphalangeal joint of the patient's third right finger was swollen and painful in clinical examination, compatible with acute monoarthritis. (Photos taken on day 2 of corticosteroid treatment). D: Skin presenting intense neutrophilic dermal infiltrate. (Biopsy taken on day 2 of corticosteroid treatment). HE 200x, zoom 1,5x. 
infections are the most common. Other infectionrelated causes include bacteria and viruses. ${ }^{8}$ The gastrointestinal infections that have been accused of provoking SS are mainly caused by Salmonella, Yersinia or Campylobacter bacteria. ${ }^{1,10}$ Yet, despite the multiple fecal and blood cultures, no pathogen was isolated and the symptoms were self-limited; therefore, the enteritis was attributed to a viral gastrointestinal infection. On admission, our patient fulfilled one of the two major criteria and three of the four minor criteria (Table 1); therefore the probability of SS was high. On day two, he started the oral corticosteroid treatment with gradual resolution of the rashes and on day four he underwent a skin biopsy, which confirmed the diagnosis of SS (Fig. 1). Musculoskeletal system, central nervous system, eyes, kidneys, gastrointestinal system, cardiovascular system, respiratory system, mouth and spleen can be the sites of extracutaneous manifestations of SS. The combination of ulcerative colitis and uveitis with SS has also been described. ${ }^{9}$ Musculoskeletal manifestations including arthralgias and myalgias have been found in $12-59 \%$ of the cases ${ }^{10}$, yet only a few reports of arthritis have been published and they usually describe asymmetric polyarthritis. , $^{9} 11,12$ Our patient presented with a monoarthritis which appeared almost simultaneously with the skin lesions and gradually resolved with the corticosteroid treatment. To the best of our knowledge, it is the first report of SS that was ignited by non-bacterial enteritis, accompanied by acute reactive monoarthritis; the uncommonness of the case is overemphasized by the fact that the malignancy-unrelated SS has a strong female predominance, with a female-to-male ratio of $15: 1 .^{13-15}$

\section{CONCLUSION}

SS, though uncommon, is an important entity to be recognized among health care providers. The clinical findings together with laboratory tests should lead to pathology confirmation and be followed by exclusion of the possibility of malignancy coexistence.

\section{CONFLICTS OF INTEREST}

None declared.

\section{REFERENCES}

1. Cohen PR. Sweet's syndrome - a comprehensive review of an acute febrile neutrophilic dermatosis. Orphanet J Rare Dis 2007;2:34.

2. Lopez-Sanchez M, Garcia-Sanchez Y, Marin AP. An unusual evolution of a pregnancy-associated Sweet's syndrome. Eur J Obstet Gynecol Reprod Biol 2008;140(2):283-5.

3. Jorizzo JL, Solomon AR, Zanolli MD, et al. Neutrophilic vascular reactions. J Am Acad Dermatol 1988;19(6):983-1005.

4. Carpentier O, Piette F, Delaporte E. Sweet's syndrome after BCG vaccination. Acta Derm Venereol 2002;82(3):221.

5. Ambrose NL, Tobin AM, Howard D. Etanercept treatment in Sweet's syndrome with inflammatory

Table 1. Summary of diagnostic criteria of Sweet Syndrome (SS) (Su WP and Liu HN, 1986)

\section{Classical SS diagnostic criteria ${ }^{15}$}

Both major criteria and 2/4 minor criteria required establish the diagnosis of classical SS

Abrupt onset of painful erythematous plaques or nodules

Major

Both are required Histopathologic evidence of a dense neutrophilic infiltrate without evidence of leukocytoclastic vasculitis

Pyrexia $>38^{\circ} \mathrm{C}$

Association with an underlying hematologic or visceral malignancy, inflammatory disease, or pregnancy, OR preceded by an upper respiratory or gastrointestinal infection or vaccination

Minor Excellent response to treatment with systemic corticosteroids or potassium iodide

$2 / 4$

are required Abnormal laboratory values at presentation (three of four):

- erythrocyte sedimentation rate $>20 \mathrm{~mm} / \mathrm{hr}$;

- positive C-reactive protein;

- $>8000$ leukocytes;

- $>70 \%$ neutrophils 
arthritis. J Rheumatol 2009;36;1348-9.

6. Kazmi SM, Pemmaraju N, Patel KP, et al Characteristics of Sweet's syndrome in patients with acute myeloid leukemia Clin Lymphoma Myeloma Leuk 2015;15(6):358-63.

7. Cohen PR. Proton pump inhibitor-induced Sweet's syndrome: report of acute febrile neutrophilic dermatosis in a woman with recurrent breast cancer Dermatol Pract Concept 2015;5(2):113-9.

8. Fett DL, Gibson LE, Su WP. Sweet's syndrome: systemic signs and symptoms and associated disorders. Mayo Clin Proc 1995;70(3):234-40.

9. Bancu LA, Ureche C, Craciun NM, et al. A case of Sweet's syndrome associated with uveitis in a young male with ulcerative colitis. RJME 2016;57(3):1145-7.

10. Moreland LW, Brick JE, Kovach RE, et al. Acute febrile neutrophilic dermatosis (Sweet syndrome): a review of the literature with emphasis on musculoskeletal manifestations. Semin Arthritis Rheum 1988; 17:143-55.

11. von den Driesch P. Sweet's syndrome (acute febrile neutrophilic dermatosis). J Am Acad Dermatol 1994;31:535-56.

12. Nolla JM, Juanola X, Valverde J, et al. Arthritis in acute febrile neutrophilic dermatosis (Sweet's syndrome). Ann Rheum Dis 1990;49:135.

13. Tuerlinckx D, Bodart E, Despontin K, et al. Sweet's syndrome with arthritis in an 8-month-old boy. J Rheumatol 1999;26(2):440-2.

14. Bourke JF, Keohane S, Long CC, et al. Sweet's syndrome and malignancy in the UK. Br J Dermatol 1997;137(4):609-13.

15. Su WP, Liu HN. Diagnostic criteria for Sweet's syndrome. Cutis 1986;37(3):167-74.

\title{
Энтерит-ассоциированный острый фебрильный нейтрофильный дерматоз с острым моноартритом
}

\author{
Стаматис С. Пападатос ${ }^{1,2}$, Христос Зисис ${ }^{2}$, Георгиос Делиянис ${ }^{2}$, Стефанос Милонас ${ }^{2}$ \\ 1 Третье отделение внутренних болезней, Национальный университет имени Каподистрии - Факультет медицины, Меди- \\ цинский университет - Афины, Многопрофильная больница „Сотириа" - Афины, Греция \\ 2 Второе отделение внутренних болезней, Многопрофильная больница „Трикала“, Тесали, Греция
}

\begin{abstract}
Адрес для корреспонденции: Стаматис С. Пападатос, Третье отделение внутренних болезней, Национальный университет имени Каподистрии - Факультет медицины, Медицинский университет - Афины, Многопрофильная больница „Сотириа" - Афины, бул. „Месогейон" 152, Афины, Греция E-mail:stamspap@gmail.com Tel:+306973750882
\end{abstract}

Дата получения: 18 февраля 2017

Дата приемки: 21 мая 2017 Дата онлайн публикации: 29 мая 2017

Дата публикации: 22 декабря 2017

Ключевые слова: синдром Свита, сыпь, моноартрит, вирусный энтерит

\section{Образец цитирования:}

Papadatos SS, Zissis C, Deligiannis G, Mylonas S. Enteritis-associated acute febrile neutrophilic dermatosis with acute monoarthritis.

Folia Medica 2017;59(4):477-80. doi:10.1515/folmed-2017-0057
Фебрильный нейтрофильный дерматоз является редко встречающимся состоянием со сложной патофизиологией, чаще всего в результате инфекции, злокачественной опухоли или аутоиммунного заболевания. Внекожные проявления заболевания тоже являются исключительно редкими. Сообщаем о пациенте с гистологически подтверждённым острым фебрильным нейтрофильным дерматозом, вызванным вирусным энтеритом, который сопровождается болезненной сыпью и острым моноартритом, которому было проведено лечение кортикостероидами. 